\title{
Academic and Professional Guidance for Tertiary Students with Disabilities: Gathering Best Practices throughout European Universities
}

\author{
Leonardo Santos Amâncio Cabral ${ }^{1 *}$, Enicéia Gonçalves Mendes², Lucia de Anna3 ${ }^{3}$, \\ Serge Ebersold 4 \\ ${ }^{1}$ Faculty of Education, Federal University of Grande Dourados, Dourados, Brazil \\ ${ }^{2}$ Department of Psychology, Federal University of São Carlos, São Carlos, Brazil \\ ${ }^{3}$ Department of Physical, Human and Health Sciences, Rome, Italy \\ ${ }^{4}$ Institut National Supérieur de formation et de recherche pour l'éducation des jeunes Handicapés et les \\ Enseignements Adaptés, Suresnes, France \\ Email: prof.leonardocabral@gmail.com
}

Received 31 May 2015; accepted 13 September 2015; published 18 September 2015

\section{Abstract}

The exponential increase of students with disabilities enrolled at universities of different countries has urged these institutions to enable some services geared to their guidance, both academic and professional level. However, the international literature shows that these initiatives, in some realities, are still disconnected from the broader socio-economic context. In order to find possible solutions to this issue, the objective of this research was to explore, in an international level, initiatives related to the academic and professional guidance of students with disabilities. In this direction this case study has been realized with the participation of 81 tertiary students with disabilities, 14 academic counselors and 68 professional mentors from Italy, France, Ireland, Denmark and England. The overall analysis of the results emerged from this research has allowed identifying, in an international perspective, the strengths of each reality explored. The reflections on these elements have directed the proposition of indicators which can contribute to the scientific and academic communities on the implementation, evaluation and monitoring of a potential academic and professional guidance program for tertiary students with disabilities.

\section{Keywords}

Disability, University, Guidance, Individual Plan, Labor Market

\section{Introduction}

The democratization of the access to the highest educational levels and the promotion of concrete opportunities

*Corresponding author.

How to cite this paper: Cabral, L.S.A., Mendes, E.G., de Anna, L. and Ebersold, S. (2015) Academic and Professional Guidance for Tertiary Students with Disabilities: Gathering Best Practices throughout European Universities. Open Journal of Social Sciences, 3, 48-59. http://dx.doi.org/10.4236/jss.2015.39008 
for professional insertion are not truly in operation within many social, economic and cultural contexts worldwide, which is looking for ways to stimulate social progress in a more inclusive way [1].

Particularly regarding the access to the Educational system, the results of the last round of the Programme for International Student Assessment (PISA) shows the increase of the enrolment, the longer permanence of the people within educational system towards the higher education and, especially since 2003, most countries have maintained or improved their perspective based on equity of access for all, even if it happened discreetly [2] [3].

However, even if we are in this mentioned context, the international report "Education at a Glance 2014: OECD Indicators" highlights that there are more than 46 millions of people unemployed throughout the OCDE countries, the rate of young population without a job is still high and the access to the social services is not enough for the most rate of the population [4].

Within this context, it is possible to deduce that the promotion of the access to the highest educational levels is not enough to ensure for the students, considering also those ones who are in tertiary level, their professional insertion, especially if the institutions does not offer programs for academic and professional guidance which aims to match with the territorial's interests within they are immersed [5]-[7].

This frame becomes more evident and delicate to intervene when we consider the demands and exigencies of the students that are with disability, even if there are evidences which indicate the difficulties to precisely identify the number and the several existent profiles in this population, the scientific literature, the national and international reports indicate a common denominator among every OCDE's country and their key partners: the significant augmentation of their enrolment rate at the university [5]-[13].

For these conditions, we cannot ignore the fact that the current moment represents the results of several particular initiatives that are thought in the history. Until the 1970's, most of young people with disabilities has not accessed ordinary schools and, consequently, the highest educational levels, such as universities [14] [15].

From 1980's, the promotion of the access of the people with disabilities to the university has increased exponentially and the referential literature has indicated yet a political tendency to develop specific programs to support people with disabilities at the transition from school to the university and to the world of work [16]-[20].

Throughout 1990's, some authors has remarked the importance to implement the improvement of these services in order to promote the scholar success of the students with disabilities through the realization of concretes professional experiences [21]-[26]. In that context, it was highlighted the conviction that people with disabilities represented an economic potential that should be considerate and, additionally, offered adequate support to overcome their difficulties [8].

In the 2000's, from this movement, it was observed an increase of the number of such services within the universities [7] [15]. Parallel to this phenomenon, tertiary students with disability felt more need to invest in their training and to practice their skills in a professional environment [27]-[29]. This led to the need to improve the prospects, policies and practices within the university context to assist students with disabilities to realize their life project [30].

Currently, opportunities for training and professionalization of people with disabilities, therefore, have expanded significantly in order to make it possible to offer the labor market new professional profiles with skills, needs and particular characteristics which, until then, were not such common, either to the employers, either to the society.

As against, this population, which represents a rate of $16 \%$ of people with disabilities in working age, encounter many obstacles in which there is the conviction that their conditions of disability has always a negative effect on the results in the labor market and, therefore, there is a higher probability of this population being in unemployed conditions [31]. Furthermore, the risk of poverty is significantly higher for people with disabilities (21.1\%) than those without disabilities (14.9\%) [32].

In this context, despite the efforts, universities still develop restricted and disconnected stock from the broader socio-economic context [33]. Afterwards, the European Union took a solid position to support the active participation of people with disabilities in society and the economy. This is evident in the "Action Plan of the European Council 2006-2015" for the promotion of rights and full participation of people with disabilities in the society" and in the strategy "Europe 2020", which aims to create a smart, sustainable and inclusive growth to build a society that includes wholes through new behaviors and practices to ensure our future [34] [35].

So it must be, however, that such work should be done not only within schools but also at the universities and in the workplace, to have a vocational education and training that meets the requirements of global socio-economic context [36] [37]. 
It means that the prerogative of the need to promote, among others, the orchestration of the accessibility in the higher education and the guidance for the professional insertion of this population, currently, appear to be a necessary and irreversible process in a current context where the application of professional capacities become increasingly a social, economic, political and cultural need for the progress of the nations.

On this basis, the question arises: how universities, over the years, are being organized to promote access and support people with disabilities in order to guarantee a congruent training to their expectations and to the requirements of the market working?

In this sense, the main objective of this study was, from the identification, to gather and systematically analyze the good practices adopted by French, Italian, English, Irish and Danish universities about the academic and vocational guidance of students with disabilities, to propose a methodology of accompaniment and support that enable an effective orchestration of accessibility into the Higher Education and the world of work.

\section{Methodology}

\subsection{The Research Approaches}

To achieve the objective of the present study, this one was carried out on the ground of French, Italian, English, Danish and Irish universities, considering the daily environment of tertiary students with disabilities. So this is a case study that is a research method which is based on the harvest of various sources of information using more detection instruments and it is recommended when it is necessary to deepen certain themes [38].

Based on this perspective, the study presented here was particularly developed through the European project "Univers' Emploi”", the Ph. D program "Culture, disabilità e inclusione: educazione formazione" and the "Programa de Pós-Graduação em Educação Especial”2. Given the fact that the object of the study is taking place in several countries, the methodology of the study was divided into two main approaches: longitudinal descriptive case study (in France, Italy, Denmark and Ireland) and an exploratory case study (England and France).

The research carried out in Italy, France, Denmark and Ireland can be characterized as descriptive because the goal was to make a complete description of a phenomenon which, in our case, is around the academic and vocational guidance for tertiary students with disabilities, taking into account the organization and the people involved [38].

After analyzing a period of two years in the context of each country, the case studies which have been conducted could be defined as longitudinal, since this was an investigation that has required a prolonged presence of the researcher in the everyday environment to understand a plurality of experiences [39].

\subsection{The Participants of the Study}

\section{The longitudinal descriptive case study (The Univers'Emploi Project):}

Students with disabilities, universities and the respective counselors: based on the enrolment year, the type of disability and gender, 81 students were selected to compose the sample of this study: 21 students in France (University of Strasbourg, University of Paris Ouest Nanterre La Défense, and University of Montpellier 1); 20 students in Italy (Università degli Studi di Roma "Foro Italico”, Università degli Studi "Roma Tre”, Università degli Studi di Messina); 20 students in Denmark (Aarhus University); 20 students in Ireland (The Trinity College of Dublin and The University College of Cork). It is important to emphasize that the study has had also the active participation of 14 counselors, whom were the responsible for the "Disability Services" of the universities involved.

Professional Mentors: In order to effectively collect the elements inherent in the transition of students with disabilities towards the labor market, some responsible for companies (public and private ones), associations and institutions (in various spheres) were aware about the objectives of the project, prospecting also the approach

\footnotetext{
${ }^{1}$ The project “Univers'Emploi” aimed to propose responses to the objective of the Action Plan 2006-2015 of the European Council for the people with disabilities (action line n 4): "to facilitate efficient and effective transitions between different phases of education and between education and employment”. The project has been coordinated by Prof. Serge Ebersold (INSHEA-France) and, particularly in each country involved, by Prof. Lucia de Anna (Università degli Studi di Roma “Foro Italico”-Italie); Prof. Willy Aastrup (Aarhus University-Danemark) and Prof. Declan Treanor (Trinity College of Dublin-Irlande). For further information, please access: http://universemploi.inshea.fr/.

${ }^{2}$ Under the coordination of Prof. Lucia de Anna (Università degli Studi di Roma "Foro Italico"-Italy), Prof. Charles Gardou (Université Lumière Lyon 2-France) and Prof. Enicéia Gonçalves Mendes (Universidade Federal de São Carlos-Brazil), the Ph.D. thesis "Orientamento accademico e professionale degli student universitari con disabilità: perspettive internazionali” has been developed by Prof. Leonardo Santos Amâncio Cabral (currently full professor at the Federal University of Grande Dourados-Brazil).
} 
among university and territory. Once familiar regarding these aims, they agreed to delegate professional mentors in their respective workplaces that could follow tertiary students with disability during their activities. A total of 68 professional mentors were involved in the two years of the study.

The exploratory case study (In France and England):

The universities and the respective counsellors: As part of the development a Ph. D. thesis, the Doctor Europeaus provides international mobility to conduct research activities in a third country [5]. The researcher was able to realize a two-month stay in France at the "l'Institut National Supérieur de formation et de recherche pour l' éducation des jeunes Handicapés et les Enseignements Adaptés (INSHEA)" and one month in England, at the University of Northampton. During this mobility, some professors ${ }^{3}$ has collaborated linking the researcher with heads of services (Mission Handicap; Disability Services) and Job Placement (Secteur Professionnel, Career Services) of two French universities (Université Sorbonne Nouvelle-Paris 3 and l'Université Paris DescartesParis 5) and two British universities (University of Northampton and University of Cambridge).

\subsection{The Collection and Data Analysis}

For the longitudinal descriptive case study (The "Univers' Emploi" Project):

Observation: The data collected through observation has been analyzed according the presence and absence of predefined indicators (student, teacher and family's participation; involvement of peers; participation of internal services; involvement of external services; evaluation/monitoring tools; the duration of the guidance; additional comments), and also on the basis of the principles of analysis of recorded data [40]. Elements inherent in the general organization of services, academic and vocational guidance activities and about the students themselves have been also analyzed.

Interviews: Items identified by interviews with students, through the assessment protocol, were organized in four categories, based on the model proposed by the University of Aarhus (Denmark) and agreed by all universities involved in this study: 1) academic aspects 2) cognitive aspects 3) social aspects 4) individual aspects of students [41].

Questionnaires: An analysis indicators form was developed to analyze the data collected and to bring out the reflections elements [5].

For the exploratory case study (In France and England):

Interviews: The semi-structured interview has been applied to those who are responsible for the Mission Handicap and Secteur Professionnele (in France) and the Access Team Ability/Disability Services and the Career Service (in England).

Anecdotal records: allowing describe the events, avoiding any evaluations or interpretations.

Sample questions: these ones were prepared to ensure the consistency of information collected.

Therefore, we can say that the present study has, substantially, a qualitative character, since there is a set of methods which are particularly sensitive to develop a systematic study around the participation process and the changes that takes place within the university and in the labor environment [39].

\section{Results}

The systematization and analysis of the data collected during the realization of the European project "Univers' Emploi" and the mentioned doctoral thesis, have allowed to read and understand several contexts regarding to the organization of academic and vocational guidance programs for students with disabilities adopted by some universities and companies from France, Italy, England, Ireland and Denmark and also about the various issues identified during this process [5] [42].

\section{Developing the Academic and Professional Individual Plan}

\subsubsection{The Academic Guidance}

Without no pretension to generalize the analysis results to the countries involved in this research, our effort has been dedicated, in this first moment, around the systematization of the information about the professionals involved in the Disability Services and the Job Placement Services of the explored universities particularly known

\footnotetext{
${ }^{3}$ In France, by the Prof. Éric Plaisance (Université Paris Descartes-Paris 5) and, in England, Prof. Cristina Devecchi (University of Northampton).
} 
as an important references regarding academic guidance process of the tertiary student with disabilities, particularly about: the involvement of the student, teacher and the family, the comrades of internal and external services, assessment instruments and duration of the guidance. As a result, the Table 1 shows the presence or absence of practices implemented by those universities, regarding academic guidance of students with disabilities:

From the evidence gathered on academic guidance, shown in the Table 1, we can say that: 1) in all the countries studied, students and teachers are involved in the academic orientation process; 2) at the universities explored in England, France, Ireland and Italy, there are other services and other students whom are involved in further supports in order to promote academic guidance; 3) In Italy and England, the family of students is more evidentially considered in the academic orientation process.

In addition, this study allows us to strength the conviction that the most important phase of the academic guidance is when the university or the labor market welcomes a student with disabilities. The university counselor and the company mentor must have the skills to individualize, in a holistic approach, the bio-psycho-social and educational aspects of the students without dropped them, encouraging their active participation [5] [7] [43].

From the first phase of reception and construction of the interpersonal relationship between student and counselor, it is possible to develop, with the active participation of the student, an Academic and Professional Individual Plan.

However, to prevent the role of academic mentor in an individual way in this process, it is important not only to actively involve the student, but also to build and maintain a link between the expert of Disability Service, with other university and territorial services. Some authors also emphasize the importance of the collaboration between teachers, faculties and academia to exchange information [15] [44]-[46]. In addition, the family is also taken into account in this process, particularly in Italy, compared to other universities studied during this study.

From an educational point of view, the initial assessment and monitoring can provide important elements which, if analyzed according to the approach of Universal Curriculum Design, can contribute to the reduction of differences between instructional strategies for all and those for people with disabilities. This reinforces the concept of educational accessibility for all and scheduled based on the approach of lifelong learning and active involvement [15] [47].

\subsubsection{The Professional Guidance}

In this perspective, the same elements can be presented in Table 2 concerning, particularly, initiatives for the

Table 1. Practices implemented by universities explored within the frame of academic guidance program for students with disabilities.

\begin{tabular}{|c|c|c|c|c|c|c|c|c|c|c|}
\hline & \multicolumn{10}{|c|}{ Academic Guidance } \\
\hline & \multicolumn{5}{|c|}{ Disability Services } & \multicolumn{5}{|c|}{ Job Placement Services } \\
\hline & IT & FR & UK & IE & DK & IT & FR & UK & IE & DK \\
\hline $\begin{array}{c}\text { Student } \\
\text { Involvement }\end{array}$ & v & v & v & v & $v$ & v & v & v & $v$ & $\checkmark$ \\
\hline $\begin{array}{l}\text { Professors } \\
\text { Involvement }\end{array}$ & v & v & v & $v$ & $\checkmark$ & v & $\checkmark$ & v & $v$ & $\checkmark$ \\
\hline $\begin{array}{c}\text { Family } \\
\text { Involvement }\end{array}$ & v & - & $v$ & - & - & $v$ & - & - & - & - \\
\hline $\begin{array}{l}\text { Colleagues } \\
\text { Involvement }\end{array}$ & v & v & v & $\checkmark$ & - & $v$ & - & - & - & - \\
\hline $\begin{array}{l}\text { Internal Services } \\
\text { Involvement }\end{array}$ & $v$ & v & v & v & - & $v$ & v & v & v & - \\
\hline $\begin{array}{l}\text { External } \\
\text { Services } \\
\text { Involvement }\end{array}$ & - & - & - & - & - & $v$ & v & v & v & - \\
\hline Assessment tools & v & v & v & $v$ & v & v & v & v & v & v \\
\hline $\begin{array}{l}\text { Guidance } \\
\text { Duration }\end{array}$ & $\begin{array}{l}\text { From } \\
\text { Initial } \\
\text { Time }\end{array}$ & $\begin{array}{l}\text { From } \\
\text { Initial } \\
\text { Time }\end{array}$ & $\begin{array}{c}\text { From } \\
\text { Initial } \\
\text { Time }\end{array}$ & $\begin{array}{c}\text { From } \\
\text { Initial } \\
\text { Time }\end{array}$ & $\begin{array}{l}\text { From } \\
\text { Initial } \\
\text { Time }\end{array}$ & During & During & During & During & During \\
\hline
\end{tabular}


Table 2. Practices implemented by universities explored as part of the vocational guidance program for students with disabilities.

\begin{tabular}{|c|c|c|c|c|c|c|c|c|c|c|}
\hline & \multicolumn{10}{|c|}{ Professional Guidance } \\
\hline & \multicolumn{5}{|c|}{ Disability Services } & \multicolumn{5}{|c|}{ Job Placement Services } \\
\hline & IT & FR & UK & IE & DK & IT & FR & UK & IE & DK \\
\hline $\begin{array}{c}\text { Student } \\
\text { Co-Involvement }\end{array}$ & v & v & v & v & v & v & v & v & v & v \\
\hline $\begin{array}{c}\text { Professors } \\
\text { Co-Involvement }\end{array}$ & v & - & v & v & - & v & v & v & v & - \\
\hline $\begin{array}{c}\text { Family } \\
\text { Co-Involvement }\end{array}$ & v & - & - & - & - & v & - & - & - & - \\
\hline $\begin{array}{c}\text { Enterprises } \\
\text { Co-Involvement }\end{array}$ & - & - & - & - & - & - & - & - & - & - \\
\hline $\begin{array}{l}\text { Internal Services } \\
\text { Co-Involvement }\end{array}$ & v & v & v & v & - & v & v & v & v & - \\
\hline $\begin{array}{l}\text { Co-Involvement } \\
\text { External Services }\end{array}$ & v & v & v & v & - & v & v & v & v & - \\
\hline $\begin{array}{l}\text { Assessment and } \\
\text { Monitoring tools }\end{array}$ & v & v & v & v & v & v & v & v & v & $v$ \\
\hline Guidance Duration & $\begin{array}{l}\text { Initial } \\
\text { Time }\end{array}$ & During & $\begin{array}{l}\text { Initial } \\
\text { Time }\end{array}$ & $\begin{array}{l}\text { Initial } \\
\text { Time }\end{array}$ & During & During & During & During & During & During \\
\hline
\end{tabular}

promotion of vocational guidance for students with disabilities:

From the evidences gathered on Professional guidance, presented in Table 2, we can say that: 1) the professional sector of universities explored in all countries involves students and teachers in the vocational/professsional guidance process; 2) within universities explored in France, Italy, England and Ireland, the service involves other university structures; 3 ) in the case of Italy, the student's family is taken into consideration; 4) The internship offices and the Job Placement offices of all universities studies involves the student and use assessment and monitoring specific tools; 5) In the universities studied in Italy, France, England and Ireland, the service involves professors from other university structures and territory; 6) Surprisingly, the data indicates that the territory of enterprises are still disconnected of the career guidance initiatives for tertiary students with disabilities.

In addition, this study supports the fact that it is essential to involve political figures in the career/profession$\mathrm{al} /$ vocational guidance initiatives for students with disabilities to make it easier to mobilize local associations and entities companies.

It is also necessary to disseminate information on access and special courses opportunities, responsive services, internships and job offers. The contact opportunities between the student and their reality could be improved by practical case situations, or in situations of official competition or in courses and learning. Moreover, there is also strong demand from employers for train tertiary students "willing to work" [48] [49].

This reinforces the importance of building a concrete career plan that meets the requests of each context, based on the approach of lifelong learning, taking into account, among others, academics and social skills of the student, the self-determination, autonomy, vocation and professional experiences [50].

The world of work demands, moreover, not only that the student has the academic abilities but also be able to acquire professional skills, whether professional, ethical values, communication skills, flexibility to adapt to change, interpersonal skills, set goals, social abilities and problem solving [51]-[53].

However, the study identified that students fear being marginalized in their academic career and to be considered incompetent by their peers or by their recruiter. Therefore, some students sometimes feel down and do not dare talk about their disabilities, especially in the workplace [54].

This attitude concerns the characteristic of self-determination which is not only about to expose their conditions, but also in reviving seek additional support, being determined to overcome obstacles, in self-knowledge, self-assessment and reflection in self-efficacy, decision making, in independence and autonomy which reflects directly on academic achievement and student's career [55]. 
In order to stimulate the self-determination and the involvement of the student, the mentor must be able to perceive how to identify the best strategy for building a trusting relationship with the student aiming to define his career. In this sense, each context must be analyzed in order to overcome the culture of marginalization and negative discrimination because this allows the student to be aware of the conditions and thus facilitate updating of support and actions appropriates to each context [56].

To set up guidance programs, so, it is important to stimulate the student to have conscience as part of a labor market in constant changes. Be creative and innovative means to be resilient and able to adapt to different situations in life, including the university and the world of work [57] [58].

In a lifelong learning approach, students should be able to understand their own value to the society of knowledge and the production in which we live. It is important to promote initiatives that enable the student to advise their own knowledge, skills and needs, at the university and world of work.

We must see the human being as an indefinite reality and always open, exceeding the temptations of simplistic dualism (ability/disability, normal/abnormal), categorization and mechanical definitions [59].

The guidance of the students must be a process during which their skills are stimulated in order to overcome situations of stigma and low self-esteem [60]. These situations have a direct effect on the transition to the world of work. Students should especially benefit from conditions enabling it to implement its civic sense and responsibility to participate in community life [7] [61] [62].

Considering that each context seeks, in its way, to meet its own requirements, the purpose of the study is not the one to identify a single model or seen better, but to identify in each country and identify good practices for effective inclusion of people with disabilities in university and the world of work, while strengthening the social role of the university, whose aim is to prepare students for their civic life.

The results of this study, therefore, allow us to assert that academic and professional guidance program for a student with disabilities must be considered in a holistic approach around the student's skills, the context of the university, the disability and career services, the territory, and when it is necessary, working with the family. At the end of this study, based on positive discrimination, has been possible to collect the best practices around this issue that might be considered to activate, stimulate or enhance similar initiatives.

Despite identifying these elements, the aim of this study was not only to identify the organization and the technical aspects, but to highlight all individual empirical, interpersonal, academic and professional aspects of the actors whom are involved in the transition process to the university and to the world of work.

From the analysis carried out in different contexts, which is intended to introduce some key elements that could be considered to activate, stimulate and/or enhance similar initiatives. That is to say that beyond discussions with the research groups of the Univers' Emploi European project and the presentations in local contexts of each country, it was possible to identify common elements that are considered essential to enable the synergy of the accessibility and the support for tertiary students with disabilities to their professional insertion (Figure 1):

Thus, we can say that to build an effective and appropriate guidance process, it must that the relationship between student and mentor be realized through: 1) promoting enabling environment for communication; 2) stimulation of the active participation; and 3) confidence, which will allow the student to feel more at ease to understand his personal, academic and social environment.

In particular, based on the results obtained, it can be said that to establish a university and vocational guidance program, it is necessary to activate, stimulate and improve the following aspects:

1) The synergy between departments, and collaboration between university and territory;

2) The organization and culture of inclusion at the university;

3) The context of interpersonal relationships between stakeholders so that he will be favorable;

4) Self-determination and motivation;

5) The skills and needs of the student.

In this direction, the following indications are also presented to the European Parliament in Strasbourg on the occasion of the release of Univers' Emploi project.

\section{Final Considerations}

The presentation of the overall results and insights obtained from the data collected, not only helped to develop an international dialogue on the theme of this research, but also to offer new instruments providing to the institution 


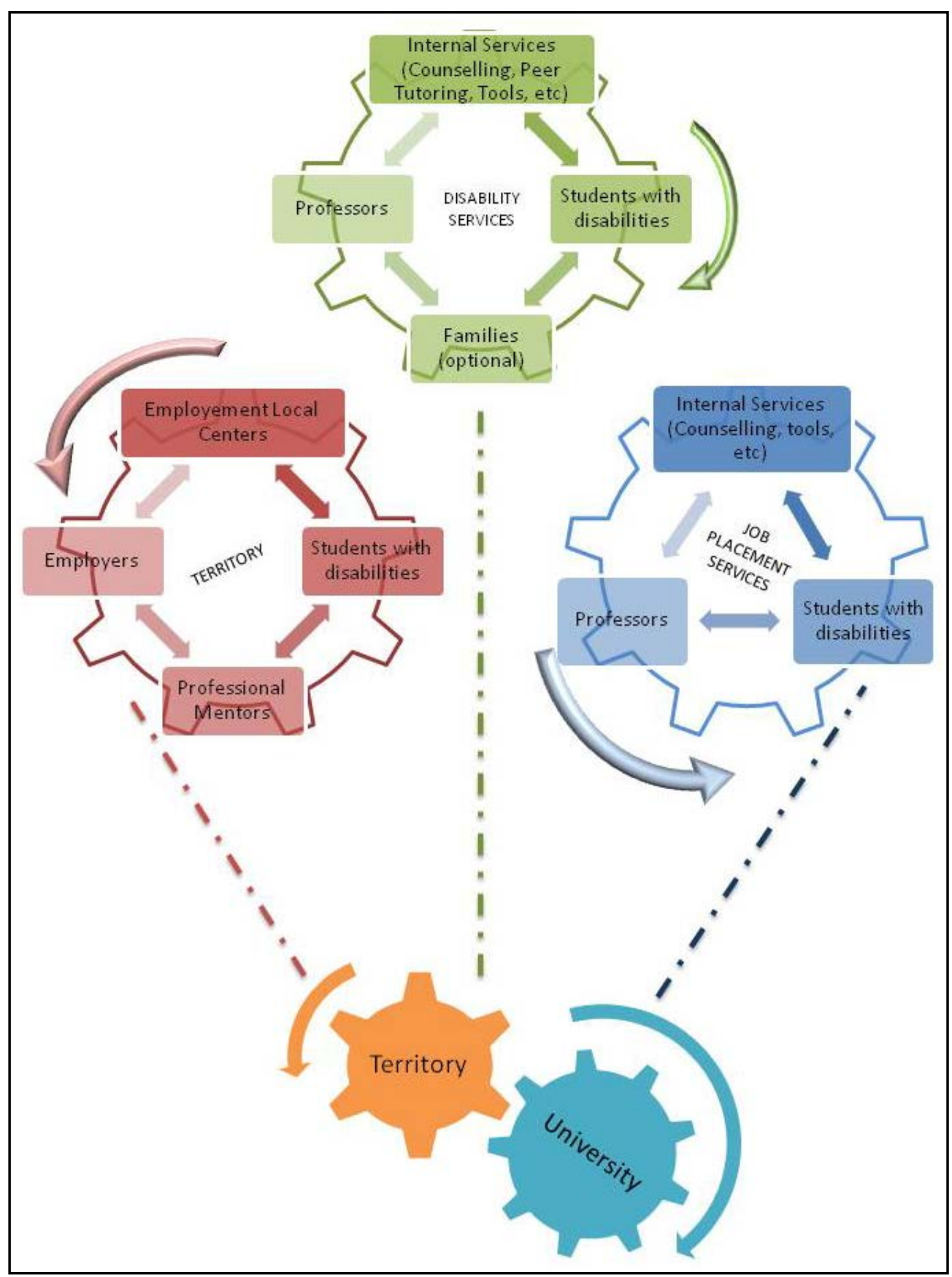

Figure 1. The synergy of the access and the professional guidance of tertiary students with disabilities. Source: Own elaboration.

concerned elements that this study in Figure 2 has identified as fundamental to establish an academic and professional guidance program for students with disabilities [5]. Moreover, from a scientific perspective, the study shows that it is important to develop research that takes into account the different themes inherent in this debate: 1) monitoring of practices implemented during the study; 2) establishment of longitudinal studies of the beginning of the course; 3) identification of the territory's requirements; 4) organization of career services; 5) adaptations to the university and the labor environment; 6) dissemination and accessibility of jobs; 7) discrimination in the world of work; 8) Social Security for Disability; 9) family counseling; 10) evaluation will follow; 11) empowerment; 12) matching between professional capacity and the world of work; 13) building a network between 
- 01 - To plan and develop from the beginning of university studies, an initial assessment and continuous monitoring of objectives and students needs, taking into account their life project, identity and motivations:

- 02 - Promote training modules and update for the university staff, especially for those ones of Disability and Professional Sectors

- 03 - Perform counseling activities to stimulate the taking of responsibility, while seeking to find solutions to problems that prevent the progress of their studies and their transitions to employment; - 04 - Promote the relationship between the student and the world of work through training activities (pre-and post-license) related to their professional interests and abilities;

- 05 - Organize activities that allow students to acquire specific skills related to the development of their CVs and personal interest;

- 06 - Match the supply and demand of the working world, based on the student's profile;

- 07 - Provide business consulting services on the professionalism of graduates with disabilities and the specific adaptations to implement in the workplace (physical accessibility, technological, human resources):

- 08 - Universities must contact the structures of the Employment Centers of the Provinces and the Centers for Orientation for work and each department in charge of these issues in order to plan and implement policies on employment and to network public and private operators of the territory;

-09 - Establish relationships with associations of local companies to promote awareness activities; -10 - Promote greater entrepreneurial opportunities for youth:

-11 - Increase participation in Scorates / Ertasmus Program (language skills) and the Leonardo Da Vinci Programme (professional experience abroad);

-12-Maintain the database with job and internship offers.

Figure 2. Essential elements on the guidance for tertiary students with disabilities. Source: Own elaboration.

the territory and universities; 14) self-determination.

In the perspective of the results presented here, of the experience around the problematic of the academic and vocational guidance for students with disabilities and from the existing indications for improving transition programs [63] and the Ph. D. thesis developed on this theme, we offer a group of indicators that could be used to the different university structures to organize a monitoring of their own academic and professional guidance program for students with disabilities [5].

Our intention, therefore, has been to continually contribute to the scientific community and the different realities, through the proposal of discussions, supported by the literature, aiming to develop not only support methods, but to present possibilities and tools for the practical implementation of guidance programs that effectively enable the orchestration of the access, permanence and success of students with disabilities in the higher education and world of work, developing ways for their own life project.

\section{Acknowledgements}

To the Ph. D. Program "Culture, disabilità, inclusion: educazione e formazione" and to the Centro Accoglienza of the Università degli Studi di Roma "Foro Italico"; to the Post-Degree Program in Special Education of the Federal University of São Carlos to support the development of this research; to the European Program "Leonardo-Vocational Education and Training Across Europe” of the Lifelong Learning Programme; and to the partners from Denmark, Ireland, England, France and Italy.

\section{References}

[1] OECD (2014) All on Board: Making Inclusive Growth Happen. OECD Publishing, OECD. http://www.oecd.org/inclusive-growth/All-on-Board-Making-Inclusive-Growth-Happen.pdf

[2] OECD (2012) Higher Education. Education Today 2013: The OECD Perspective. OECD Publishing.

[3] OECD (2013) PISA 2012 Results: Excellence through Equity (Volume II): Giving Every Student the Chance to Succeed, PISA. OECD Publishing, Paris. 
[4] OECD (2014) Education at a Glance 2014: OECD Indicators. OECD Publishing.

[5] Cabral (2013) L'orientamento accademico e professionale degli studenti universitari com disabilità: perspettive internazionali. Thesis PhD in Culture, disabilità e inclusione: Educazione e formazione. Università degli Studi di Roma "Foro Italico", Italy. http://www.bdtd.ufscar.br/htdocs/tedeSimplificado//tde_busca/arquivo.php?codArquivo=5842

[6] Ebersold, S. (2008) L’adaptation de l'enseignement supérieur au handicap: Évolution, enjeux et perspectives. Dans OECD (Org). L’enseignement supérieur à l'horizon 2030-Démographie, OCDE, Paris, 241-261.

[7] Ebersold, S. (2014) Orchestration de l'accessibilité, handicap et enseignement supérieur. In: Legos, P., Ed., Les Processus Discriminatoires Des Politiques du Handicap, Presses Universitaires de Grenoble, Grenoble, 147-167.

[8] De Anna, L. (1996) L’accoglienza degli studenti disabili nelle Università. Notiziario bimestrale del Ministero dell' Università e della Ricerca Scientifica e Tecnologica. Collana Università Ricerca, Roma, 24-48.

[9] National Center for Education Statistics (NECS) (2009) Digest of Education Statistics 2008. US Department of Education, Washington DC.

[10] Ministère De L’enseignement Supérieur et De La Recherche (2010) Effectifs des étudiants handicapés en universités, Paris.

[11] OECD (1999) Inclusive Education at Work: Students with Disabilities in Mainstream Schools. OECD, Paris.

[12] OECD (2003) Disability in Higher Education. OECD, Paris.

[13] OECD (2011) Inclusion of Students with Disabilities in Tertiary Education and Employment: Education and Training Policy. OECD Publishing.

[14] Mendes, E.G. (2006) A radicalização do debate sobre inclusão escolar no Brasil. Revista Brasileira de Educação, 33 387-405.

[15] Defur, S.H. and Korinek, L. (2008) The Evolution toward Lifelong Learning as a Critical Transition Outcome for the 21st Century. Exceptionality, 16, 178-191.

[16] Brown, J.M. and Kayser, T.F. (1981) Articulation: Enhancing Special Needs Students’ Transitions from Secondary to Postsecondary Vocational Education Programs. Career Development for Exceptional Individuals, 4, 3-7.

[17] Riffel, R. and Hartley, N. (1981) Articulating Secondary Special Needs Groups into Postsecondary Programs: Some Directions for Future Research. Career Development for Exceptional Individuals, 4, 83-89.

[18] Cordoni, B. (1982) A Directory of College LD Services. Journal of Learning Disabilities, 15, 529-534.

[19] Dexter, B.L. (1982) Helping Learning Disabled Students Prepare for College. Journal of Learning Disabilities, 15, 344-346.

[20] Brolin, D. and Elliott, T.R. (1984) Meeting the Lifelong Career Development Needs of Students with Handicaps: A Community College Model. Career Development for Exceptional Individuals, 7, 12-21.

[21] Norlander, K.A., Shaw, F.M. and McGuire, H.M. (1990) Competencies of Postsecondary Education Personnel Serving Students with Learning Disabilities. Journal of Learning Disabilities, 23, 426-432.

[22] Brinckerhoff, L.C., Shaw, S.F. and Mcguire, J.M. (1992) Promoting Access, Accommodations, and Independence for College Students with Learning Disabilities. Journal of Learning Disabilities, 25, 417-429.

[23] Rusch, F.R., Kohler, P.D. and Rubin, S. (1994) Descriptive Analysis of OSERS-Sponsored Postsecondary Education Model Programs. Career Development for Exceptional Individuals, 17, 53-63.

[24] Yost, D.S., Shaw, S.F., Cullen, J.P. and Bigaj, S.J. (1994) Practices and Attitudes of Postsecondary LD Service Providers in North America. Journal of Learning Disabilities, 27, 631-640.

[25] Day, S.L. and Edwards, B.J. (1996) Assistive Technology for Postsecondary Students with Learning Disabilities. Journal of Learning Disabilities, 29, 486-492.

[26] Raskind, M.H. and Higgins, E.L. (1998) Assistive Technology for Postsecondary Students with Learning Disabilities: An Overview. Journal of Learning Disabilities, 31, 27-40.

[27] Landmark, L.J., Ju, S. and Zhang, D. (2010) Substantiated Best Practices in Transition: Fifteen Plus Years Later. Career Development for Exceptional Individuals, 33, 165-176.

[28] Repetto, J.B., Mcgorray, S.P., Wang, H., Podmostko, M., Andrews, W.D., Lubbers, J. and Gritz, S. (2011) The High School Experience: What Students with and without Disabilities Report as they Leave School. Career Development for Exceptional Individuals, 34, 142-152.

[29] Carter, E.W., Austin, D. and Trainor, A.A. (2012) Predictors of Postschool Employment Outcomes for Young Adults with Severe Disabilities. Journal of Disability Policy Studies, 23, 50-63.

[30] Booth, T. and Ainscow, M (2002) Index for INCLUSION: Developing Learning and Participation in Schools. Centre for Studies on Inclusive Education, United Kingdom. 
[31] Halabisky, D. (2014) Entrepreneurial Activities in Europe-Entrepreneurship for People with Disabilities. OECD, Employment Policy Papers, 6, OECD Publishing.

[32] Hauben, H., Coucheir, M., Spooren, J., Mcananey, D. and Delfosse, C. (2012) Assessing the Impact of European Governments' Austerity plans on the Rights of People with Disabilities. European Foundation Centre (Dir.), European Report, $19-24$.

[33] Guimarães, C.F. (2011) Ações inclusivas para permanência das pessoas com deficiência no ensino superior: Um estudo em IES de Natal/RN. Universidade Federal do Rio Grande do Norte, Brésil.

[34] D’europe, C. (2006) Comite des Ministres. Recommandation Rec (2006) 5du Comité des Ministres aux Etats membres sur le Plan d'action du Conseil de l'Europe pour la promotion des droits et de la pleine participation des personnes handicapées à la société: Améliorer la qualité de vie des personnes handicapées en Europe-2006-2015. http://www.coe.int/t/dg3/disability/ActionPlan/PDF/Rec_2006_5_Francais.pdf

[35] European Commission (2010) Communication from the Commission-Europe 2020: A Strategy for Smart, Sustainable and Inclusive Growth. http://eur-lex.europa.eu/LexUriServ/LexUriServ.do?uri=COM:2010:2020:FIN:EN:PDF

[36] Hogstedt, C., Wegman, D.H. and Kjellstrom, T. (2007) The Consequences of Economic Globalisation on Working Conditions, Labor Relations and Workers' Health. In: Kawachi, I. and Wamal, S. (Dir.), Globalisation and Health, Oxford University Press, Oxford.

[37] Maclean, R. and Lai, A. (2011) Future of Technical and Vocational Education and Training: Global Challenges and Possibilities. International Journal of Training Research, 9, 2-15.

[38] Lucisano, P. and Salerni, A. (2002) Metodologia della ricerca in educazione e formazione. Carocci editore, Roma.

[39] Sorzio, P. (2006) La ricerca qualitativa in educazione: Problemi e metodi. Carocci, Roma.

[40] Bardin, L. (2002) Análise de conteúdo. Edições, Lisboa.

[41] La Tour, Cabral and Rachedi-Nasri (2012) Enhancing Transition to Work for Students with Disability-A Guidance Methodology: The Synthesis Report. Suresnes: INSHEA.

[42] Ebersold, S. (2010) Developing a Support Methodology of Disabled Students Allowing to Conjugate Effectively Academic Sucess and Access to Employment. ADAM: Leonardo da Vinci Programme (2010-1-FR1-LEO05-14481).

[43] De Anna, L. (2003) Alla ricerca del proprio futuro. Universitas, 89, 17-22.

[44] Mcneela E., Shevlin M. and Kenny M. (2004) Participation in Higher Education for Students with Disabilities: An Irish perspective. Disability \& Society, 19, 15-30.

[45] Grasselli, B. and Ciccani, P. (2005) La rappresentazione sociale delle persone con disabilità. Un dialogo culturale sui passaggi fondamentali del percorso di integrazione. Rivista Della SCUOLA Superiore Dell'Economia e Delle Finanze, 2, 119-126.

[46] Patrick, C., Peach, D., Pocknee, C., Webb, F., Fletcher, M. and Pretto, G. (2009) The WIL Report: A National Scoping Study. Australian Learning and Teaching Council FINAL Report. Queensland University of Technology, Brisbane.

[47] Maori Tertiary Reference Group (2003) Maori Tertiary Education Framework. Ministry of Education, Wellington.

[48] Green, W., Hammer, S. and Star, C. (2009) Facing up the Challenge: Why Is It So Hard to Develop Graduate Attributes? Higher Education Research \& Development, 28, 17-29.

[49] Trede, F.V. (2010) Enhancing Communicative Spaces for Fieldwork Education in an Inland Regional Australian University. Higher Education Research \& Development, 2, 373-387.

[50] Lamb, P. (2007) Implications of the Summary of Performance for Vocational Rehabilitation Counselors. Career Development for Exceptional Individuals, 30, 3-12.

[51] Martin, J.E., Mithaug, D.E., Cox, P., Peterson, L.Y., Van Ducke, J.L., and Cash, M.E. (2003) Increasing Self-Determination: Teaching Students to Plan, Work, Evaluate, and Adjust. Exceptional Children, 69, $431-447$.

[52] Bartlett, T. (2004) Back from the Brink: More Colleges Try to Help Students Who Struggle with Their Courses. The Chronicle of Higher Education, 50, 37-58.

[53] Cassner-Lotto, J. and Barrington, L. (2006) Are They Really Ready to Work? Employers' Perspectives on the Basic Knowledge and Applied Skills of New Entrants to the 21st Century Workforce. http://www.p21.org/storage/documents/FINAL_REPORT_PDF09-29-06.pdf

[54] Kakela, M., and Witte, R. (2000) Self-Disclosure of College Graduates with Learning Disabilities. Learning Disabilities: A Multidisciplinary Journal, 10, 25-31.

[55] Heiman, T. and Precel, K. (2003) Students with Learning Disabilities in Higher Education: Academic Strategies Profile. Journal of Learning Disabilities, 36, 248-258.

[56] Trotter, E. and Cove, G. C. (2005) Student Retention: An Exploration of the Issues Prevalent on a Vocational Degree 
Programme with Mainly Mature Students. Learning in Health and Social Care, 4, 29-42.

[57] Malaguti, E. (2005) Educarsi alla resilienza: Come affrontare crisi e difficoltà e migliorarsi. Erickson, Trento.

[58] Stallman, H. (2011) Embedding Resilience within the Tertiary Curriculum: A Feasibility Study. Higher Education Research \& Development, 30, 121-133.

[59] Gardou, C. (2006) Diversità, vulnerabilità e handicap: Per una nuova cultura della disabilità. Trento, Erickson.

[60] Kundu, M., Dutta, A., Schiro-Geist, C. and Crandall, L. (2003). Disability Related Services: Needs and Satisfaction of Post-Secondary students. Rehabilitation Education, 17, 45-54.

[61] Canevaro, A. (2005) L’università, gli studenti disabili e il loro progetto di vita. Integrazione Scolastica e Sociale, 4, 113-124.

[62] De Anna, L. (2007) Riflessioni sulla Conferenza Internazionale "Le buone Prassi per l'Integrazione e l'inclusione”. L'Integrazione Scolastica e Sociale, 6, 9-26.

[63] National Alliance for Secondary Education And Transition. (2005) National Standards and Quality Indicators: Transition Toolkit for Systems Improvement. Minneapolis: University of Minnesota, National Center on Secondary Education and Transition. 